\title{
Urgences
}

\section{Rock garden : october}

\section{D.G. Jones}

Numéro 16, mars 1987

D.G. Jones : d'un texte, d'autres

URI : https://id.erudit.org/iderudit/025367ar

DOI : https://doi.org/10.7202/025367ar

Aller au sommaire du numéro

Éditeur(s)

Urgences

ISSN

0226-9554 (imprimé)

1927-3924 (numérique)

Découvrir la revue

Citer ce document

Jones, D. (1987). Rock garden : october. Urgences, (16), 9-9.

https://doi.org/10.7202/025367ar

Ce document est protégé par la loi sur le droit d'auteur. L'utilisation des services d'Érudit (y compris la reproduction) est assujettie à sa politique d'utilisation que vous pouvez consulter en ligne.

https://apropos.erudit.org/fr/usagers/politique-dutilisation/
Cet article est diffusé et préservé par Érudit.

Érudit est un consortium interuniversitaire sans but lucratif composé de l'Université de Montréal, l'Université Laval et l'Université du Québec à Montréal. Il a pour mission la promotion et la valorisation de la recherche. https://www.erudit.org/fr/ 


\section{D.G. Jones \\ ROCK GARDEN: OCTOBER}

In the rain, it is a ruin of shadows, it is

the tomb of flowers

It gathers the colours

5 of fallen leaves. Still

it is the stones that flower

like a gathering of tomes

where those that are gone go on talking

10 More and more my mouth is full of stones and the bones of my colleagues

look like flowers

Is it, the jumble, paradise

15

or Angkor Wat

or the inner city after

10 P.M.? It is not

alive or dead

or human. I pass it

20 in the rain, darkly. It is

a growth of runes 